DOI: 10.46340/eppd.2021.8.2.22

Darya Derevyanko

ORCID ID: https://orcid.org/0000-0002-5907-9580

Lviv State University of Internal Affairs, Ukraine

\title{
LEGAL REGULATION OF NOTARIAL PROTECTION OF INDIVIDUALS' CORPORATE RIGHTS
}

\author{
Дар'я Дерев'янко \\ Львівський державний університет внутрішніх справ, Україна

\section{ПРАВОВЕ РЕГУЛЮВАННЯ НОТАРІАЛЬНОЇ ОХОРОНИ КОРПОРАТИВНИХ ПРАВ ФІЗИЧНИХ ОСІБ}

\begin{abstract}
After the proclamation of independence and the declaration of the market vector of development in our country, the practice of creating business entities with the status of legal entities has become widespread. Immediately many problems have appeared associated with the violation of property and non-property rights of the founders (participants) of such legal entities and other stakeholders, in particular, creditors, heirs and more. Corporate rights can belong to both individuals and legal entities and other participants in civil relations (for example, the state). The scientific article has substantiated the importance of the place of notarial protection of corporate rights in the legal mechanism of ensuring the interests of participants of legal entities. Notarial protection of corporate rights of individuals may be carried out both when a notary performs notarial acts and when a notary performs the functions of a state registrar. Certain problems in the legal regulation of such protection are emphasized. In particular, there is a difference in the legal regulation of corporate interests' protection in the establishment of joint stock companies with the participation of individuals by the Civil Code of Ukraine and the Law of Ukraine "On Joint Stock Companies». In addition, the approach to the protection of the participants' rights of private enterprises and limited liability companies is different. In this regard, it is considered appropriate to make a number of changes to the current legislation of Ukraine to expand the scope of mandatory notarial forms of contracts, as well as certification of signatures on documents related to the activities of corporate legal entities. The necessity of legislative consolidation of the requirement for notarization of the decisions on creation, acts of acceptance-transfer of the shares in the authorized capital of legal entities of private law of any organizational and legal forms is substantiated.
\end{abstract}

Keywords: notary, corporate rights, natural person, legal entity, protection, defense.

Постановка проблеми. Охорона корпоративних прав займає важливе місце в правовому механізмі забезпечення інтересів учасників юридичних осіб корпоративного типу, що, своєю чергою, $\epsilon$ життєво необхідним для України в умовах розвитку ринкових відносин та інтеграції до Свропейського співтовариства. Після проголошення незалежності та декларування ринкового вектору розвитку у нашій державі широкого поширення набула практика створення суб'єктів господарювання зі статусом юридичних осіб. Відразу виникло і безліч проблем, пов'язаних з порушенням майнових і немайнових прав як засновників (учасників) таких юридичних осіб, так i інших заінтересованих, зокрема, кредиторів, спадкоємців тощо. Відтак, питання належного правового регулювання охорони на даний час є актуальними.

Аналіз останніх досліджень. Питання правового регулювання нотаріальної охорони корпоративних прав були предметом дослідження багатьох вітчизняних науковців, серед яких: М.М. Дякович, О.Р. Кібенко, В.М. Коссак, І.М. Кучеренко, М.В. Оприско, І.В. Спасибо-Фатєєва, В.І. Цікало, Ю.М. Юркевич та багато інших. Поряд з цим, вивчення даної наукової проблематики в умовах сучасних євроінтеграційних процесів необхідно продовжувати.

Постановка завдання. Метою цієї статті $є$ виконання детального науково-теоретичного дослідження проблем правового регулювання нотаріальної охорони корпоративних прав фізичних 
осіб та вироблення на його основі авторської позиції з приводу доцільності удосконалення чинного законодавства України у цій сфері.

Виклад основного матеріалу. Відповідно до п. 14 ч. 1 ст. 92 Конституції України ${ }^{1}$, організація і діяльність нотаріату підлягають визначенню виключно на рівні законів України. Досліджуючи проблеми охорони і захисту сімейних прав та інтересів нотаріусом, М.М. Дякович відзначила, що нотаріат є органом, якому держава делегувала повноваження стосовно здійснення захисту і охорони інтересів суб'єктів сімейних відносин у будь-яких випадках, якщо вони не суперечать засадам цивільного (сімейного) законодавства, у зв'язку з чим сімейний інтерес може отримати охорону і захист під час вчинення нотаріальної дії нотаріусом, що жодним чином не пов'язано з фактом чи можливістю його порушення ${ }^{2}$. Підтримуючи таку думку та вважаючи іiі достатньо обгрунтованою, вважаємо, що схожа ситуація має місце і увипадку охорони корпоративних прав. Так, при дослідженні регулятивних правовідносин можемо простежити, що за наслідками виконання нотаріусом своїх повноважень забезпечується охорона інтересів суб'єктів корпоративних відносин у будь-яких випадках, що не суперечать законодавству і таким чином корпоративний інтерес $є$ об'єктом правової охорони незалежно від того порушений він чи тільки існує загроза такого порушення.

Корпоративні права можуть належати як фізичним особам, так і юридичним особам та іншим учасникам цивільних відносин (наприклад, державі).

Як стверджує О.Р. Кібенко, усе, що так чи інакше пов'язано з діяльністю господарських товариств $\epsilon$ предметом регулювання норм корпоративного права ${ }^{3}$. На думку В.І. Цікала, корпоративне правовідношення $\epsilon$ різновидом цивільного зобов'язального правовідношення, яке реалізується виконанням зобов'язаною стороною покладених на неї обов'язків ${ }^{4}$. Подібно, I.М. Кучеренко вважає необгрунтованим висновок, що корпоративні права можуть бути об'єктом права власності, оскільки, наприклад, учасник господарського товариства, відчужуючи акцію чи частку, не укладає договору на відчуження корпоративних прав, оскільки акції та частка самі по собі є об'єктом права власності, які тягнуть за собою перехід корпоративних прав

Позаяк, варто погодитися з І.В. Спасибо-Фатєєвою, що корпоративне право можна коротко визначити як сукупність правових норм, регулюючих відносини, що складаються між корпорацією та iii учасниками (корпоративні правовідносини) ${ }^{6}$.

При цьому, правове регулювання нотаріальної охорони корпоративних прав фізичних осіб (так же, як і інших суб'єктів корпоративних прав) забезпечується перш за все такими нормативноправовими актами, як: Цивільний кодекс України ${ }^{7}$ Господарський кодекс України ${ }^{8}$, Закон України «Про нотаріат» ${ }^{9}$, Закон України «Про державну реєстрацію юридичних осіб, фізичних осібпідприємців та громадських формувань» ${ }^{10}$, Закон України «Про акціонерні товариства» ${ }^{11}$, Закон України «Про господарські товариства» ${ }^{12}$, Закон України «Про товариства 3 обмеженою

\footnotetext{
${ }^{1}$ Конституичія Украӥни, 1996 (Верховна Рада України). Офічіийний сайт Верховної Ради Украӥни <https://zakon.rada.gov.ua/laws/show/254\%D0\%BA/96-\%D0\%B2\%D1\%80/conv\#Text> (2020, січень, 19).

2 Дякович, М. М. (2014). Охорона і захист сімейних прав та інтересів нотаріусом: Монографія. Київ: Істина, 83. ${ }^{3}$ Кибенко, Е. Р. (1999). Корпоративное право. Учебное пособие. Харьков: Эспада, 41.

${ }^{4}$ Цікало В. Корпоративне правовідношення: правова природа та зміст. Юридичний радник, 5, 45-51.

${ }^{5}$ Кучеренко, I. М. (2004). Організачійно-правові форми юридичних осіб приватного права: Монографія. Київ: Інститут держави і права ім. В.М.Корецького НАН України, 198.

${ }^{6}$ Спасибо-Фатєєва, І. В. (2014). Вчення про корпоративні права і цивілістична доктрина. Право Украӥни, 6, 84.

${ }^{7}$ Цивільний кодекс Украӥни, 2003 (Верховна Рада України). Офіційний сайт Верховної Ради Украӥни $<$ https://zakon.rada.gov.ua/laws/show/435-15/conv\#Text> (2020, січень, 19).

${ }^{8}$ Господарський кодекс Украӥни, 2003 (Верховна Рада України). Офіційний сайт Верховної Ради Украйни <https://zakon.rada.gov.ua/laws/show/436-15\#Tеxt> (2020, січень, 19).

9 Закон Про нотаріат, 1993 (Верховна Рада України). Офіиійний сайт Верховної Ради Украӥни <https://zakon.rada.gov.ua/laws/show/3425-12\#Tеxt> (2020, січень, 19).

10 Закон Про державну реєстрацію юридичних осіб, фізичних осіб-підприємиів та громадських формувань, 2003 (Верховна Рада України). Офіиійний сайт Верховної Ради Украӥни

<https://zakon.rada.gov.ua/laws/show/755-15\#Text> (2020, січень, 19).

11 Закон Про акціонерні товариства, 2008 (Верховна Рада України). Офічійний сайт Верховної Ради Украӥни

<https://zakon.rada.gov.ua/laws/show/514-17\#Text> (2020, січень, 19).

12 Закон Про господарські товариства, 1991 (Верховна Рада України). Офіційний сайт Верховної Ради

України <https://zakon.rada.gov.ua/laws/show/1576-12/conv\#Text> (2020, січень, 19).
} 
та додатковою відповідальністю» ${ }^{1}$, Наказ Міністерства юстиції України «Про затвердження Порядку вчинення нотаріальних дій нотаріусами України» ${ }^{2}$ і т.д.

Поряд із тим, у частині, що стосується нотаріальної охорони корпоративних прав фізичних осіб, вважаємо за доцільне акцентувати увагу, зокрема, на таких нормативно закріплених правилах:

- за змістом ст. 126 ЦК України, справжність підпису учасника повного товариства на заяві про вихід із нього підлягає нотаріальному посвідченню (такі ж правила передбачені ст. 71 Закону України «Про господарські товариства»);

-відповідно до абз. 3 ч. 2 ст. 153 ЦК України передбачено обов'язковість нотаріального посвідчення договору про створення акціонерного товариства, створюваного фізичними особами;

- згідно з ч. 3 ст. 113 ГК України, учасники приватних підприємств наділені правом встановлювати вимоги нотаріального посвідчення правочинів, предметом яких $є$ частки таких учасників у статутних капіталах та скасовувати такі вимоги із внесенням відповідних відомостей до Єдиного державного реєстру юридичних осіб, фізичних осіб-підприємців та громадських формувань. При цьому, встановлення та скасування таких вимог за своєю правовою природою $є$ односторонніми правочинами, які підлягають нотаріальному посвідченню;

-у ст. 9, 10 Закону України «Про акціонерні товариства» встановлено, що: а) у випадку створення товариства за участю фізичних осіб необхідно засвідчувати їхні підписи на засновницькому договорів; б) у випадку заснування товариства єдиним засновником - фізичною особою, необхідно засвідчити ії підпис на рішенні про намір заснувати акціонерне товариство; в) у випадку заснування однією фізичною особою акціонерного товариства необхідно нотаріально засвідчити їі підпис на рішенні щодо заснування;

-ст. 30 Закону України «Про акціонерні товариства» передбачає механізм, згідно з яким у разі невиплати дивідендів відповідно до визначених Законом строку та умов, акціонер набуває право звернутися до нотаріуса щодо вчинення виконавчого напису на документах, за якими стягнення заборгованості може бути здійснене у безспірному порядку (щодо цього варто згадати, що В.М. Коссак слушно вказував на необхідність передбачення у законодавстві норм, які дієво забезпечували обов'язок органів управління акціонерних товариств скеровувати на виплату дивідендів частину прибутку таких товариств $\left.{ }^{3}\right)$;

- ст. 39 Закону України «Про акціонерні товариства» передбачає, що довіреність на право участі та голосування при проведенні загальних зборів від імені фізичної особи посвідчується нотаріусами, іншими посадовими особами, які вчиняють нотаріальні дії чи депозитарною установою, а від імені юридичної особи - видається іiі органом чи уповноваженою особою відповідно до установчих документів;

-у відповідності до ч. 2 ст. 5 Закону України «Про товариства з обмеженою та додатковою відповідальністю», учасники товариств можуть встановлювати вимоги: нотаріального засвідчення справжності підписів під час прийняття рішень усфері діяльності відповідних товариств, нотаріального посвідчення правочинів, предметом котрих виступають частки у статутних капіталах товариств, як і скасовувати перелічені вимоги і т.д.;

-ч. 4 ст. 8 Закону України «Про товариства з обмеженою та додатковою відповідальністю» встановлює необхідність нотаріального посвідчення безвідкличних довіреностей з корпоративних прав (аналогічна норма міститься у ст. 26-2 Закону України «Про акціонерні товариства» щодо акціонерних товариств);

- відповідно до ст. 11 Закону України «Про товариства з обмеженою та додатковою відповідальністю», справжність підписів учасників на першій редакції статутів товариств засвідчують нотаріально. Також, наведеною нормою передбачено нотаріальне засвідчення підписів учасників чи уповноважених осіб на: змінах до статутів та на перших редакціях статутів реорганізованих товариства; рішеннях про створення, щодо провадження діяльності на підставі

\footnotetext{
1 Закон Про товариства з обмеженою та додатковою відповідальністю, 2018 (Верховна Рада України). Офіційний сайт Верховної Ради України <https://zakon.rada.gov.ua/laws/show/2275-19\#Tехt> (2020, січень, 19). ${ }^{2}$ Наказ Про затвердження порядку вчинення нотаріальних дій нотаріусами Украӥни, 2012 (Міністерство юстиції України). Офіційний сайт Верховної Ради Украӥни 〈https://zakon.rada.gov.ua/laws/show/z0282-12\#Text> (2020, січень, 19).

${ }^{3}$ Коссак, В. М. (2012). Проблеми захисту майнового права міноритарних акціонерів на отримання дивіденду. Проблеми охорони прав суб'єктів корпоративних правовідносин. Матеріали Міжнародної науково-практичної конференції (23-24 вересня 2011). Івано-Франківськ, 78.
} 
модельних статутів (окрім рішень на порталі електронних сервісів, підписаних кваліфікованим електронним підписом);

-відповідно до ст. 21 Закону України «Про товариства 3 обмеженою та додатковою відповідальністю», учасники вправі встановлювати та скасовувати вимоги нотаріального посвідчення правочинів з відчуження чи застави часток із внесенням цих відомостей до Єдиного державного реєстру судових рішень (як слушно звертає увагу М.В. Оприско, запроваджений у ЦК України принцип свободи договору дозволяє укладати також договори, якими буде опосередковуватися перехід корпоративних прав від однієї особи до іншої і які не передбачені в ЦК України, тобто непоіменовані, змішані тощо ${ }^{1}$;

-ст. 35 Закону України «Про товариства з обмеженою та додатковою відповідальністю» передбачає можливість заочного голосування із необхідністю нотаріального засвідчення підпису на документів, з якого вбачається волевиявлення учасника товариства;

- ст. 36 Закону України «Про товариства з обмеженою відповідальністю» визначає особливості прийняття рішень загальних зборів учасників шляхом опитування та встановлює необхідність нотаріального засвідчення справжності підпису учасників на документах про їхнє волевиявлення;

-відповідно до ч. 1, 14 ст. 5 Закону України «Про державну реєстрацію юридичних осіб, фізичних осіб-підприємців та громадських формувань», нотаріус вправі вправі виконувати функції державного реєстратора та є суб'єктом державної реєстрації;

- відповідно до ст. 15, 17 Закону України «Про державну реєстрацію юридичних осіб, фізичних осіб-підприємців та громадських формувань» встановлено вимоги: а) нотаріального засвідчення підпису заявника у разі подання заяви про державну реєстрацію поштовим відправленням; б) нотаріального засвідчення підписів голови та секретаря загальних зборів учасників на рішеннях, що подаються для державної реєстрації змін до відомостей про юридичну особу, за винятками, встановленими Законом; в) нотаріального засвідчення підписів на установчому документі юридичної особи, крім випадків, визначених у Законі; г) нотаріального засвідчення підписів на передавальному акті чи розподільчому балансі юридичних осіб; г) нотаріального засвідчення копій окремих документів, які подають для державної реєстрації юридичної особи; д) нотаріального засвідчення підписів на заявах про вступ та вихід із товариств 3 обмеженою відповідальністю тощо;

- відповідно до п. 2.9. Глави 14 Порядку вчинення нотаріальних дій нотаріусами України, затвердженого Наказом Міністерства юстиції України від 22.02.2012, визначено особливе значення призначення нотаріусом виконавця заповіту у разі, якщо предметом заповіту виступає майно, стосовно якого після відкриття спадщини виникає необхідність управління, зокрема ці питання постають у випадку спадкування часток у статутному капіталі товариств, акцій, приватних підприємств тощо.

На підставі вищевикладеного можемо зробити висновок, що нотаріальна охорона корпоративних прав фізичних осіб може здійснюватися у двох площинах:

- при вчиненні нотаріусом нотаріальних дій;

- при виконанні нотаріусом функцій державного реєстратора.

Незважаючи на загалом достатнє регулювання відносин, пов'язаних із охороною нотаріусом корпоративних прав фізичних осіб, вважаємо за необхідне звернути увагу на окремі неточності та невідповідності, які підлягають вирішенню та про окремі з яких уже вказувалося у юридичній літературі.

Перш за все звертає на себе увагу відмінність у правовому регулюванні ЦК України та Законом України «Про акціонерні товариства» охорони корпоративних інтересів при заснуванні акціонерних товариств за участю фізичних осіб. Як вже зазначалося, ЦК України зазначає обов'язковість нотаріального посвідчення договору про створення акціонерних товариств, а Закон України «Про акціонерні товариства» - засвідчення підпису фізичної особи на засновницькому договорі. На вказану проблематику звертали увагу, зокрема, такі вчені як О.М. Гнатів ${ }^{2}$ та Ю.М. Юркевич³.

\footnotetext{
${ }^{1}$ Оприско, М. В. (2010). Поняття та види договорів про відчуження корпоративних прав. Адвокат, $11,38$.

${ }^{2}$ Гнатів, О. (2012). Правова природа засновницького договору. Проблеми державотворення $i$ захисту прав людини в Украӥні. Матеріали ХVІІІ регіон. наук.-практ. конф. (Львів, 26-27 січня 2012). Львів: Юридичний факультет Львівського національного університету імені Івана Франка, 179-180.

${ }_{3}^{3}$ Юркевич, Ю. М. (2014). Поняття та ознаки засновницького договору. Актуальні проблеми вдосконалення чинного законодавства Украӥни: Збірник наукових статей. Івано-Франківськ: Прикарпатський національний університет імені Василя Стефаника, 34, 209.
} 
Не вдаючись у дискусію $з$ приводу термінологічної тотожності понять «договір про створення акціонерного товариства», «установчий договір» та «засновницький договір», вважаємо за можливе підтримати аргументи про доцільність уніфікації підходів та внесення змін до Закону України «Про акціонерні товариства», які б передбачали обов'язкове нотаріальне посвідчення засновницьких договорів у таких випадках.

Врешті, аналізуючи проблеми нотаріальної охорони та захисту корпоративних прав учасників товариств з обмеженою відповідальністю, М.М. Дякович також звертала увагу на доцільність обов'язкової вимоги про нотаріальне засвідчення засновницького договору. ${ }^{1}$ Більше того, цілком обгрунтованою є думка про існування підстав для запровадження обов'язкової нотаріальної форми договору між вкладниками та командитними товариствами ${ }^{2}$. Продовжуючи розгляд цієї проблематики, не можемо не відзначити, що послідовно було б закріпити обов'язковість нотаріальної форми засновницьких договорів повних і командитних товариств (про що також зазначалося у наукових джерелах ${ }^{3}$ ), а також нотаріального засвідчення підпису єдиного повного учасника командитного товариства на переоформленій із засновницького договору одноособовій заяві.

Поряд $з$ тим не можна погодитися із тезою, що встановлення обов'язку нотаріально засвідчувати підписи усіх учасників на установчих документах юридичних осіб є надлишковим обтяженням, оскільки, з одного боку, закріпивши таке правило, закон, з іншого боку, дозволяє за рішенням загальних зборів уповноважити лише голову та секретаря зборів на підписання установчих документів ${ }^{4}$. Власне, така вимога, хоча й не вирішує усіх проблем, однак дисциплінує учасників відповідних корпоративних відносин, сприяє удосконаленню механізмів захисту у випадку порушенню їхніх прав як цивільного-правових, так і тих, котрі мають кримінально-правове забезпечення.

Крім цього, зважаючи на відмову вітчизняного законодавця від обов'язковості печаток, відсутність 32011 року будь-яких дозвільних процедур на їх виготовлення, доцільними є також зміни до ст. 39 Закону України «Про акціонерні товариства», які б передбачали, що довіреність на право участі та голосування при проведенні загальних зборів від імені юридичної особи видається їі органом чи уповноваженою особою відповідно до установчих документів та посвідчується нотаріусами, іншими посадовими особами, які вчиняють нотаріальні дії чи депозитарною установою.

Окрім того, станом на сьогодні неоднаковим $є$ підхід при охороні прав учасників приватних підприємств, які у більшості випадків створюються як юридичні особи корпоративного типу і мало чим відрізняються від господарських товариств, і товариств 3 обмеженою відповідальністю під час застосування Закону України «Про державну реєстрацію юридичних осіб, фізичних осіб-підприємців та громадських формувань» та під час вирішення судових спорів.

Для прикладу, при поданні учасниками приватних підприємств (на відміну від товариств з обмеженою відповідальністю) рішень щодо їх створення, державними реєстраторами не вимагається нотаріального засвідчення підписів їхніх учасників, оскільки Закон України «Про товариства з обмеженою та додатковою відповідальністю» не застосовують до таких організаційноправових форм юридичних осіб.

Натомість, наприклад при розгляді апеляційної скарги у справі № 914/1876/14 за позовом про визнання недійсними рішень загальних зборів учасників приватного підприємства «ЕкспресЗв’язок», оформлених у Протоколі від 08.07.2013 p. № 3 та про визнання недійсним договору дарування частки у статутному капіталі цього підприємства, беручи до уваги законодавчу неврегульованість порядку відчуження часток устатутному капіталі таких юридичних осіб, Львівський апеляційний господарський суд застосував положення законодавства про товариства з обмеженою відповідальністю до приватних підприємств за аналогією закону 5 .

\footnotetext{
${ }^{1}$ Дякович, М. М. (2016). Нотаріальний захист та охорона корпоративних прав засновників (учасників) товариства з обмеженою відповідальністю: цивільно-правові аспекти. Порівняльно-аналітичне право, 4, 67.

2 Юркевич, Ю. М. (2017). Договірні форми об’єднань фізичних та юридичних осіб у цивільному праві України: дисертація на здобуття наукового ступеня доктора юридичних наук. Львів: Львівський Національний Університет імені Івана Франка, 38.

${ }^{3}$ Там само, 309.

4 там само, 307.

${ }^{5}$ Постанова у справі № 914/1876/14, 2017 (Львівського апеляційного господарського суду). Сдиний державний реєстр судових рішень <https://reyestr.court.gov.ua/Review/64434192> (2020, січень, 31).
} 
Такий підхід був сприйнятий та застосований в силу неодноразового перегляду цієї справи у касаційному порядку ${ }^{1234}$.

Враховуючи вищеподане, вважаємо, що правила про необхідність нотаріального засвідчення на рішеннях про створення, актах приймання-передачі часток у статутному капіталі тощо юридичних осіб приватного права будь-яких організаційно-правових форм мають бути законодавчо закріплені.

Висновки. Підсумовуючи вищенаведене, вважаємо за можливе зазначити про важливість місця охорони корпоративних прав у правовому механізмі забезпечення інтересів учасників юридичних осіб корпоративного типу. Нотаріальна охорона корпоративних прав фізичних осіб може здійснюватися як при вчиненні нотаріусом нотаріальних дій, так і при виконанні нотаріусом функцій державного реєстратора. При цьому, до чинного законодавства України доцільно внести низку змін щодо розширення сфери застосування обов'язкової нотаріальної форми договорів усфері корпоративних відносин, як i засвідчення підписів на документах, пов'язаних із діяльністю юридичних осіб корпоративного типу.

\section{References:}

1. Konstytutsiya Ukrayiny, 1996 (Verkhovna Rada Ukrayiny) [Constitution of Ukraine, 1996 (Verkhovna Rada of Ukraine)]. Ofitsiynyy sayt Verkhovnoyi Rady Ukrayiny [Official site of the Verkhovna Rada of Ukraine] <https://zakon.rada.gov.ua/laws/show/254\%D0\%BA/96-\%D0\%B2\%D1\%80/conv\#Text> (2020, January, 19). [in Ukrainian].

2. Hnativ, O. (2012). Pravova pryroda zasnovnytskoho dohovoru [Legal nature of the memorandum of association]. Problemy derzhavotvorennya i zakhystu prav lyudyny v Ukrayini. Materialy XVIII rehion. nauk.-prakt. konf. (Lviv, 26-27 sichnya 2012) [Problems of state formation and protection of human rights in Ukraine. Materials XVIII region. scientific-practical conf. (Lviv, January 26-27, 2012)]. Lviv: Yurydychnyy fakultet Lvivskoho natsionalnoho universytetu imeni Ivana Franka, 179-180. [in Ukrainian].

3. Hospodarskyy kodeks Ukrayiny, 2003 (Verkhovna Rada Ukrayiny) [Economic Code of Ukraine, 2003 (Verkhovna Rada of Ukraine)]. Ofitsiynyy sayt Verkhovnoyi Rady Ukrayiny [Official site of the Verkhovna Rada of Ukraine] $<$ https://zakon.rada.gov.ua/laws/show/436-15\#Text> (2020, January, 19). [in Ukrainian].

4. Dyakovych, M. M. (2014). Okhorona i zakhyst simeynykh prav ta interesiv notariusom: Monohrafiya [Protection and defense of family rights and interests by a notary: Monograph]. Kyiv: Istyna. [in Ukrainian].

5. Dyakovych, M. M. (2016). Notarialnyy zakhyst ta okhorona korporatyvnykh prav zasnovnykiv (uchasnykiv) tovarystva z obmezhenoyu vidpovidalnistyu: tsyvilno-pravovi aspekty [Notarial protection and protection of corporate rights of founders (participants) of a limited liability company: civil law aspects]. Porivnyalno-analitychne pravo [Comparative and analytical law], 4, 67. [in Ukrainian].

6. Zakon Pro aktsionerni tovarystva, 2008 (Verkhovna Rada Ukrayiny) [Law on Joint Stock Companies, 2008 (Verkhovna Rada of Ukraine)]. Ofitsiynyy sayt Verkhovnoyi Rady Ukrayiny [Official site of the Verkhovna Rada of Ukraine] <https://zakon.rada.gov.ua/laws/show/514-17\#Text> (2020, January, 19). [in Ukrainian].

7. Zakon Pro hospodarski tovarystva, 1991 (Verkhovna Rada Ukrayiny) [Law on Business Associations, 1991 (Verkhovna Rada of Ukraine)]. Ofitsiynyy sayt Verkhovnoyi Rady Ukrayiny [Official site of the Verkhovna Rada of Ukraine] <https://zakon.rada.gov.ua/laws/show/1576-12/conv\#Text> (2020, January, 19). [in Ukrainian].

8. Zakon Pro derzhavnu reyestratsiyu yurydychnykh osib, fizychnykh osib-pidpryyemtsiv ta hromadskykh formuvan, 2003 (Verkhovna Rada Ukrayiny) [Law on State Registration of Legal Entities, Individual Entrepreneurs and Public Associations, 2003 (Verkhovna Rada of Ukraine)]. Ofitsiynyy sayt Verkhovnoyi Rady Ukrayiny [Official site of the Verkhovna Rada of Ukraine] <https://zakon.rada.gov.ua/laws/show/755-15\#Text> (2020, January, 19). [in Ukrainian].

9. Zakon Pro notariat, 1993 (Verkhovna Rada Ukrayiny) [Law on Notaries, 1993 (Verkhovna Rada of Ukraine)]. Ofitsiynyy sayt Verkhovnoyi Rady Ukrayiny [Official site of the Verkhovna Rada of Ukraine] <https://zakon.rada.gov.ua/laws/show/3425-12\#Text> (2020, January, 19). [in Ukrainian].

10. Zakon Pro tovarystva z obmezhenoyu ta dodatkovoyu vidpovidalnistyu, 2018 (Verkhovna Rada Ukrayiny) [Law on Limited and Additional Liability Companies, 2018 (Verkhovna Rada of Ukraine)]. Ofitsiynyy sayt Verkhovnoyi Rady

\footnotetext{
${ }^{1}$ Постанова у справі № 914/1876/14, 2014 (Вищий господарський суд України). Сдиний державний реєстр судових рімень $<$ https://reyestr.court.gov.ua/Review/41900298> (2020, січень, 31).

${ }^{2}$ Постанова у справі № 914/1876/14, 2015 (Вищий господарський суд України). Сдиний державний реєстр судових рімень $<$ https://reyestr.court.gov.ua/Review/50907857> (2020, січень, 31).

${ }^{3}$ Постанова у справі № 914/1876/14, 2016 (Вищий господарський суд України). Сдиний державний реєстр судових рімень $<$ https://reyestr.court.gov.ua/Review/59631510> (2020, січень, 31).

${ }^{4}$ Постанова у справі № 914/1876/14, 2017 (Вищий господарський суд України). Єдиний держсавний реєстр судових рімень $<$ https://reyestr.court.gov.ua/Review/65855281> (2020, січень, 31).
} 
Ukrayiny [Official site of the Verkhovna Rada of Ukraine] 〈https://zakon.rada.gov.ua/laws/show/2275-19\#Text> (2020, January, 19). [in Ukrainian].

11. Kibenko, Ye. R. (1999). Korporativnoye pravo. Uchebnoye posobiye [Corporate right. Tutorial]. Kharkiv: Espada. [in Ukrainian].

12. Kossak, V. M. (2012). Problemy zakhystu maynovoho prava minorytarnykh aktsioneriv na otrymannya dyvidendu [Problems of protection of property rights of minority shareholders to receive dividends]. Problemy okhorony prav subyektiv korporatyvnykh pravovidnosyn. Materialy Mizhnarodnoyi naukovo-praktychnoyi konferentsiyi (23-24 veresnya 2011) [Problems of protection of the rights of subjects of corporate legal relations. Proceedings of the International Scientific and Practical Conference (September 23-24, 2011)]. Ivano-Frankivsk, 78-80. [in Ukrainian].

13. Kucherenko, I. M. (2004). Orhanizatsiyno-pravovi formy yurydychnykh osib pryvatnoho prava: Monohrafiya [Organizational and legal forms of legal entities of private law: Monograph]. Kyiv: Instytut derzhavy i prava im. V.M.Koretskoho NAN Ukrayiny. [in Ukrainian].

14. Nakaz Pro zatverdzhennya poryadku vchynennya notarialnykh diy notariusamy Ukrayiny, 2012 (Ministerstvo yustytsiyi Ukrayiny). [Order on approval of the procedure for performing notarial acts by notaries of Ukraine, 2012 (Ministry of Justice of Ukraine).] Ofitsiynyy sayt Verkhovnoyi Rady Ukrayiny [Official site of the Verkhovna Rada of Ukraine] <https://zakon.rada.gov.ua/laws/show/z0282-12\#Text> (2020, January, 19). [in Ukrainian].

15. Oprysko, M. V. (2010). Ponyattya ta vydy dohovoriv pro vidchuzhennya korporatyvnykh prav [Oprisko, MV (2010). The concept and types of agreements on the alienation of corporate rights]. Advokat [Lawyer], 11, 35-39.

16. Postanova u spravi № 914/1876/14, 2014 (Vyshchyy hospodarskyy sud Ukrayiny) [Resolution in case № 914/1876/14, 2014 (Supreme Commercial Court of Ukraine)]. Yedynyy derzhavnyy reyestr sudovykh rishen [Unified state register of court decisions] <https://reyestr.court.gov.ua/Review/41900298> (2020, January, 31). [in Ukrainian].

17. Postanova u spravi № 914/1876/14, 2015 (Vyshchyy hospodarskyy sud Ukrayiny). [[Resolution in case № 914/1876/14, 2015 (Supreme Commercial Court of Ukraine)]. Yedynyy derzhavnyy reyestr sudovykh rishen [Unified state register of court decisions]<https://reyestr.court.gov.ua/Review/50907857> (2020, January, 31). [in Ukrainian].

18. Postanova u spravi № 914/1876/14, 2016 (Vyshchyy hospodarskyy sud Ukrayiny). [Resolution in case № 914/1876/14, 2016 (Supreme Commercial Court of Ukraine)]. Yedynyy derzhavnyy reyestr sudovykh rishen [Unified state register of court decisions]<https://reyestr.court.gov.ua/Review/59631510> (2020, January, 31). [in Ukrainian].

19. Postanova u spravi № 914/1876/14, 2017 (Vyshchyy hospodarskyy sud Ukrayiny). [Resolution in case № 914/1876/14, 2017 (Supreme Commercial Court of Ukraine)]. Yedynyy derzhavnyy reyestr sudovykh rishen [Unified state register of court decisions] <https://reyestr.court.gov.ua/Review/65855281> (2020, January, 31). [in Ukrainian].

20. Postanova u spravi № 914/1876/14, 2017 (Lvivskyy apelyatsiynyy hospodarskyy sud) [Resolution in case № 914/1876/14, 2017 (Lviv Commercial Court of Appeal)] Yedynyy derzhavnyy reyestr sudovykh rishen) [Unified state register of court decisions]<https://reyestr.court.gov.ua/Review/64434192> (2020, January, 31). [in Ukrainian].

21. Spasybo-Fatyeyeva, I. V. (2014). Vchennya pro korporatyvni prava i tsyvilistychna doktryna [The doctrine of corporate rights and civil doctrine]. Pravo Ukrayiny [Law of Ukraine], 6, 84. [in Ukrainian].

22. Цивільний кодекс Украӥни, 2003 (Verkhovna Rada of Ukraine)]. Ofitsiynyy sayt Verkhovnoyi Rady Ukrayiny [Official site of the Verkhovna Rada of Ukraine] <https://zakon.rada.gov.ua/laws/show/435-15/conv\#Text> (2020, January, 19). [in Ukrainian].

23. Tsikalo, V. (2006). Korporatyvne pravovidnoshennya: pravova pryroda ta zmist [Corporate legal relationship: legal nature and content]. Yurydychnyy radnyk [Legal adviser], 5, 45-51. [in Ukrainian].

24. Yurkevych, Yu. M. (2017). Dohovirni formy obyednan fizychnykh ta yurydychnykh osib u tsyvilnomu pravi Ukrayiny [Contractual forms of associations of individuals and legal entities in the civil law of Ukraine]: dysertatsiya na zdobuttya naukovoho stupenya doktora yurydychnykh nauk [dissertation for the degree of Doctor of Laws]. Lviv: Lvivsky Natsionalny Universytet imeni Ivana Franka. [in Ukrainian].

25. Yurkevych, Yu. M. (2014). Ponyattya ta oznaky zasnovnytskoho dohovoru [The concept and features of the memorandum of association]. Aktualni problemy vdoskonalennya chynnoho zakonodavstva Ukrayiny: Zbirnyk naukovykh statey [Actual problems of improvement of the current legislation of Ukraine: Collection of scientific articles]. Ivano-Frankivsk: Prykarpatskyy natsionalnyy universytet imeni Vasylya Stefanyka, 34, 202-211. [in Ukrainian]. 